\title{
Prospective Foreign Language Teacher Candidates' Views on the Use of Communication Technologies in Foreign Language Education and Their Self-Efficacy Beliefs: Case of Erbil, Iraq
}

\author{
Bunyamin Celik ${ }^{1}$ \\ ${ }^{1}$ Department of Languages, Faculty of Education, Tishk International University, Erbil, Iraq \\ Correspondence: Bunyamin Celik, Tishk International University, Erbil, Iraq. \\ Email: bunyamin.celik@tiu.edu.iq
}

Doi: $10.23918 /$ ijsses.v8i1p59

\begin{abstract}
The aim of this study was to determine the factors affecting the self-efficacy beliefs of the candidates and the use of communication technologies in foreign language education. In the 2019 - 2020 academic year, 87 senior students of ELT Department of Tishk International University Faculty of Education participated in the study. The research data were analyzed and interpreted by using qualitative research method. The results of the research showed that most of the participants were positive about the use of communication technologies for teaching purposes, and that these technologies were both a resource and a tool for practicing foreign languages, and the biggest disadvantage was the lack of technological infrastructure and security. In addition, most of the prospective teachers who participated in the research showed that they found themselves sufficient in the use of communication technologies for teaching purposes. The most important factor that positively affected the students' self-efficacy perceptions was stated as the use of information and communication technologies in the course activities. The lack of infrastructure and the technical problems encountered were put forward as factors affecting the self-efficacy perception negatively.
\end{abstract}

Keywords: Foreign Language Teacher, English Language Teaching, Communication Technologies, SelfEfficacy

\section{Introduction}

In today's world where science and technology are developing rapidly, it is no longer possible to transfer and memorize knowledge with traditional teaching methods. Curriculum programs have been changed in this regard. Instead of educating individuals who are loaded with knowledge based on memorization, it is necessary to educate individuals who think free, creative, and scientific, question events, produce solutions by realizing problems, have decision-making ability, produce knowledge, and have high self-confidence. Accordingly, student-centered education should be preferred, and a free education environment should be prepared for the students. The rapid development and change in information technologies and communication techniques in our globalizing world has affected every area of society life. While these developments directly change the communication and relationship between individuals, educational institutions like every institution in the society have been affected.

Received: December 17, 2020

Accepted: February 12, 2021

Celik, B. (2021). Prospective Foreign Language Teacher Candidates' Views on the Use of Communication

Technologies in Foreign Language Education and Their Self-Efficacy Beliefs: Case of Erbil, Iraq. International Journal of Social Sciences \& Educational Studies, 8(1), 59-72. 
The shift to the information society, the most evident feature of which is constant change, has led to the necessity of restructuring the societies of this day because the needs of the societies have changed. Therefore, the use of communication technologies for teaching purposes has become a necessity in the education of individuals who make up the information society. This makes it necessary to carry out teacher training practices which are one of the most important dimensions of the social education process with a contemporary perspective (Ertmer, Ottenbreit-Leftwich \& York, 2006). According to Bates and Poole (2003), prospective teachers should acquire the necessary knowledge and skills in the use of information technologies and communication techniques in their learning processes at university. They should be able to use these for different purposes such as teaching and professional development during their pre-service education and teaching experiences. Within this framework, prospective teachers should have opportunities to use technology in different contexts during their education. Thanks to the use of information technologies and communication techniques, it enables the storage of all kinds of information in digital media and enables students to work with materials suitable for their age and needs. The lack of time and space problems in accessing information, the ease of accessing original sources and similar factors made foreign language education an important part of this phenomenon.

In foreign language education, four basic skills are tried to be gained: "reading", "writing", "listening" and "speaking". It provides students with multiple learning environments with the use of information technologies and communication techniques both inside and outside of the classroom to acquire these four basic skills. A foreign language learner can access various types of text written in a foreign language visually and audibly through computer, increase vocabulary, interactively perform rich grammar exercises, see the pronunciation of a word and use examples in a sentence, make use of translation programs, chat friend in improving communication skills, improve their linguistic competence in less time by accessing scientific publications in libraries, read and listen to news in foreign languages (Celik, 2019; Sysoyev \& Evstigneev, 2014; Ghasemi \& Hashemi, 2011). From a psychological perspective, communication technologies provide an individual with a free learning environment. It is emphasized that learning through electronic devices is a learning style that is free from the pressure of teachers who directs, supervises, criticizes, assigns, and judges the individual, emphasizes learner autonomy, and contributes to the development of an individual's self-control skills (Mayer, 2013). Lee, (2000) lists the advantages of language-assisted language education in terms of motivation, increasing student achievement, providing different resources in language teaching, high interaction opportunities, enabling individualization of instruction, and global learning. On the other hand, the negative effects of the use of computers, mobile phones, tablets, and internet, which are the leading communication technologies, can be listed as: validity and reliability of existing information, physical disturbances because of too long time in front of electronic devices, disruptions in communication with the social environment, lack of technical information, inefficient use of time and so on (Chu, 2014; Markus, 1994). In addition, when the teaching practices supported using communication technologies in foreign language education in the literature is examined, it is seen that several theoretical and technology-based factors such as motivation, attitude, insufficiency of technological infrastructure, trained staff and similar application process affect the quality of learning and academic success in parallel. One of these factors is the perception of self-efficacy within the context of Albert Bandura's Social Cognitive Theory. "Perceived self - efficacy that affects people's beliefs in their ability to influence events that affect their lives. This core belief is the foundation of human motivation, performance accomplishments, and emotional well-being (Bandura, 2006). According to Zimmerman 
(2000), self-efficacy is generally defined as the judgment of the individual about how successful he / she can be in dealing with the difficult situations in the future. Self-efficacy belief provides the individual with a foundation for motivation, happiness, and personal success (Mart, 2013a; Mart, 2013b). This is because individuals have less willingness to act or face difficulties unless their actions have the desired results (Pajares, 2002).

According to social cognitive theory, there is a mutual relationship between individuals' personal characteristics, environment and behaviors. This mutual relationship is a determining factor in the formation of self-efficacy perceptions of individuals. Self-efficacy perception can determine the individual's next behavior. However, it is also affected by the consequences of previous behaviors. The consequences of long-term negative behaviors lead to decreased learning for individuals (Yildiz, 2020; Tschannen-Moran \& Hoy, 2007). One of the most important factors affecting self-efficacy beliefs is the experiences performed by the individual directly. The fact that the experience is in the direction of the individual's expectation and the success of the process can increase the self-efficacy belief. On the other hand, individuals can reach a certain conclusion about their abilities by monitoring the performance of other individuals around them (Hoy \& Spero, 2005). This situation indirectly affects the self-efficacy belief because of the interactions between the environment and the individual and the events taking place in the social environment of the individual.

When international studies on learning-teaching processes and the use of communication technologies are examined, it is seen that individuals' perceptions of self-efficacy are affected by different variables such as gender, attitude towards technology and experience. For example, Huffman, Whetten \& Huffman (2013) stated that female students who have less confidence in their abilities and less interest in computers avoid experiences that can improve their computer competences.

Another study related to the use of communication technologies and self-efficacy concept in foreign language education is a study conducted by Korkut and Akkoyunlu (2008) on foreign language teacher candidates' knowledge and computer literacy self-efficacy. The findings of this study showed that all the pre-service teachers were able to use computers. In addition, when the computer literacy self-efficacy of prospective teachers according to gender variable was examined, the findings of the study showed that there was a significant difference in favor of men. In a study conducted by Shirbagi (2011) in the autonomous region of Iraqi Kurdistan, 260 university graduate students' research difficulties and perceptions of self-efficacy were examined. The results indicated that although female students faced more problems about the difficulties of doing research, they were less worried than their male counterparts, whereas male students had more self-efficacy skills than female students.

This study, which was conducted to reveal the factors affecting the beliefs of self-efficacy and use of instructional communication technologies of foreign language teacher candidates, is thought to contribute to national literature. In this context, the following factors related to foreign language teacher candidates were tried to be put forward:

- The aims, advantages and disadvantages of instructional communication technologies, their views on the problems they face, 
- Determining the self-efficacy perceptions related to the use of communication technologies and affecting their beliefs positively and negatively.

\section{Research Methodology}

\subsection{Research Group}

The study group consisted of 87 fourth grade students who participated in the study on a voluntary basis from 103 students studying at ELT Department of Tishk International University Education Faculty in 2019 - 2020 academic year. A purposive sampling approach was adopted in the determination of the study group. In purposeful sampling, the researcher identifies the participants with the most appropriate and desired characteristics as the sample with their own judgment (Etikan, Musa \& Alkassim, 2016). In addition, $58(67 \%)$ of the students were female and $29(33 \%)$ were male.

\subsection{Data Collection and Data Collection Tools}

Data collection was carried out by the researchers. 87 students in the study group were firstly informed about the research and data collection tool in the general classroom environment. The students expressed their opinions in writing through the questionnaires distributed to them. In this study, a questionnaire developed by the researcher was used to reveal the factors affecting the beliefs and self-efficacy beliefs of foreign language teacher candidates' communication technologies.

This survey consists of three parts:

Part One: Determination of the personal information of the students participating in the research,

Part Two: Determination of the level and frequency of use of information and communication technologies (related devices),

Part Three: Open-ended questions are given in which students can express their self-efficacy beliefs in using communication technologies for instructional purposes.

To ensure the validity of the questionnaire, the opinions of two researchers who are experts in the fields of computer and instructional technologies and foreign language education were used. The draft questionnaire prepared by the researchers was presented to the opinion of the experts, and the proposed form was finalized with the proposed arrangements within the framework of the opinions.

\subsection{Analysis of Data}

The quantitative data obtained in the study were analyzed by using descriptive statistics technique in the form of frequencies and percentages (Mertler \& Reinhart, 2016). In the analysis of the data obtained from open-ended questions, content analysis technique used in qualitative research methods was implemented. The technique of content analysis is carried out in cases where the research cannot be expressed theoretically very clearly or when a more in-depth analysis is needed (Hsieh \& Shannon, 2005).

Intercoder Reliability Assessment (ICR) was conducted by researchers for the reliability of the themes and findings obtained during the content analysis process (Lombard, Snyder-Duch \& Bracken, 2002). In this 
study, firstly, raw data were transferred to the computer by the researchers. Then one of the researchers created themes with the content analysis technique. The themes that were agreed upon and the differences of opinion were determined with the study conducted by the other researcher on the themes obtained. As a result of this process, coefficients were calculated for each theme with the help of ICR Coefficient $=$ Consensus / (Consensus + Disagreement) formula and the themes calculated as 75 and above were accepted as reliable.

\section{Findings and Interpretation}

Findings related to the use of communication technologies in foreign language education of prospective foreign language teachers and their self-efficacy beliefs:

Table 1 shows the frequency and level of use of hardware products of foreign language teacher candidates in their daily lives and teaching communication technologies. Especially in the last 10 years, a significant increase in the use of this device has been determined thanks to the technological equipment and features of smartphones. This is explained by the fact that a single device can do all the work of many other communication technology devices. As a matter of fact, $100 \%$ of all students use their mobile phones frequently and their level of use is determined as 100\%. This was followed by $95 \%$ USB memory and 94\% Smart TV, the most popular communication technology device in the last 10 years. As a matter of fact, the level of use of both devices is at the highest level. In addition, it has been observed that the Laptop, which has a usage frequency of $82 \%$, is used more than Desktop Personal Computer (38\%) because it is portable. In addition, students' ability to use these devices is at the highest level. The data showed that most students somehow use hardware products of communication technologies. On the other hand, 94\% of students stated that they never used Sound Recorder, $91 \%$ of them never used electronic dictionaries and $69 \%$ of them never used Digital Cameras.

As it can be clearly seen from the data in the table, it is seen that foreign language teacher candidates find themselves sufficient in terms of using the products of communication technologies. $100 \%$ of the students stated that they could use their mobile phones and Smart Television / Equipment, 98\% Laptop and 93\% Personal computer, 92\% USB memory USB Memory (flash drives) based on their individual knowledge and skills. $46 \%$ of the students can use Printer and $42 \%$ can use Scanner without the help of anyone else. The usability rate of these devices was found to be average, but lower than other devices. In addition to these findings, another reason why the frequency and usage levels of communication technology products are generally so high can be explained as follows: the devices are more technological especially in the last 10 years, easy to use, high in accessibility, high in variety, reasonable in prices and can be used in many other stages of life other that education. 
Table 1: Frequency and usage levels of computer and hardware products

\begin{tabular}{|c|c|c|c|c|c|c|c|c|c|c|c|c|}
\hline \multirow{3}{*}{\begin{tabular}{l}
\multicolumn{2}{c}{ Communication Technology } \\
Hardware
\end{tabular}} & \multicolumn{6}{|c|}{ Frequency of usage } & \multicolumn{6}{|c|}{ Level of Use } \\
\hline & \multicolumn{2}{|l|}{ 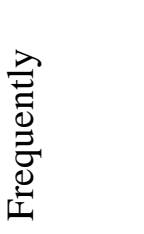 } & \multicolumn{2}{|l|}{ 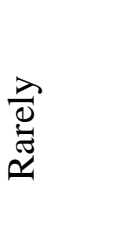 } & \multicolumn{2}{|l|}{$\begin{array}{l}\bar{D} \\
\vec{u} \\
\bar{z}\end{array}$} & \multicolumn{2}{|r|}{ 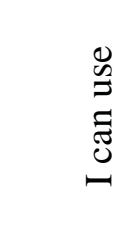 } & \multicolumn{2}{|c|}{ 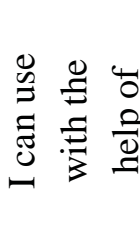 } & \multicolumn{2}{|l|}{ 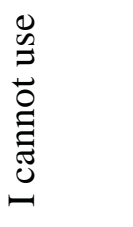 } \\
\hline & $\mathrm{f}$ & $\%$ & $\mathrm{f}$ & $\%$ & $\mathrm{f}$ & $\%$ & & $\%$ & $\mathrm{f}$ & $\%$ & $\mathrm{f}$ & $\%$ \\
\hline Personal computer (PC) & 33 & 38 & 50 & 57 & 4 & 5 & 81 & 93 & 6 & 7 & 0 & 0 \\
\hline Laptop & 71 & 82 & 14 & 16 & 2 & 2 & 85 & 98 & 2 & 2 & 0 & 0 \\
\hline Smart Phone / Mobile Phone & 87 & 10 & 0 & 0 & 0 & 0 & 87 & 10 & 0 & 0 & 0 & 0 \\
\hline Pocket PC / Tablet & 38 & 44 & 45 & 51 & 4 & 5 & 80 & 92 & 2 & 2 & 0 & 0 \\
\hline Printer & 44 & 51 & 28 & 32 & 15 & 17 & 28 & 32 & 40 & 46 & 19 & 22 \\
\hline Scanner & 22 & 25 & 53 & 61 & 12 & 14 & 30 & 34 & 36 & 42 & 21 & 24 \\
\hline Smart Television / Equipment & 82 & 94 & 5 & 6 & 0 & 0 & 87 & 10 & 0 & 0 & 0 & 0 \\
\hline CD/DVD Writer & 13 & 15 & 20 & 23 & 54 & 62 & 17 & 19 & 34 & 39 & 36 & 42 \\
\hline Web Camera & 29 & 33 & 47 & 54 & 11 & 13 & 65 & 74 & 18 & 21 & 4 & 5 \\
\hline Video Camera & 12 & 14 & 58 & 67 & 17 & 19 & 69 & 80 & 9 & 10 & 9 & 10 \\
\hline DVD/VCD Player & 17 & 19 & 61 & 70 & 9 & 11 & 68 & 79 & 12 & 14 & 7 & 7 \\
\hline USB Memory (flash drive) & 83 & 95 & 3 & 3 & 1 & 2 & 80 & 92 & 5 & 6 & 2 & 2 \\
\hline Digital Cameras & 8 & 9 & 19 & 22 & 60 & 69 & 58 & 67 & 27 & 31 & 2 & 2 \\
\hline Electronic Dictionary & 3 & 3 & 5 & 6 & 79 & 91 & 86 & 99 & 1 & 1 & 0 & 0 \\
\hline Sound Recorder & 2 & 2 & 14 & 16 & 82 & 94 & 57 & 66 & 19 & 22 & 11 & 12 \\
\hline
\end{tabular}

Table 2 shows the foreign language teacher candidates' finding themselves enough or not about the use of instructional communication technologies and hardware products based on their gender. According to the data in Table 2, 88\% of female students and 93\% of male students find themselves sufficient in using communication technologies for teaching purposes. In general, $91 \%$ of the students in the study group stated that they found themselves sufficient in terms of instructional communication technologies. In addition, the fact that most of the female students participating in the research find themselves sufficient in terms of communication technologies and the use of hardware products shows a positive effect in terms of everyone with the developing technology. 
Table 2: Self-efficacy perceptions of foreign language teacher candidates about the use of instructional communication technologies and hardware products

\begin{tabular}{|l|l|l|l|l|}
\hline \multirow{2}{*}{ Teacher Candidates } & \multicolumn{2}{|c|}{ I find myself sufficient } & \multicolumn{2}{c|}{$\begin{array}{c}\text { I do not find myself } \\
\text { sufficient }\end{array}$} \\
\cline { 2 - 5 } & $f$ & $\%$ & $f$ & $\%$ \\
\hline Female $(\mathrm{n}=58)$ & 51 & 88 & 7 & 12 \\
\hline Male $(\mathrm{n}=29)$ & 27 & 93 & 2 & 7 \\
\hline Total $(\mathrm{n}=87)$ & 77 & 91 & 10 & 9 \\
\hline
\end{tabular}

Information on the frequency of use of the Internet, which is a global electronic communication network, is given in Table 3 based on gender. According to this, $7 \%$ of female students use internet for 1 hour and less, $32 \%$ use 1-2 hours a day and $71 \%$ use internet 3 hours or more. It was determined that $6 \%$ of male students use internet for 1 hour or less, $14 \%$ for $1-2$ hours per day and $80 \%$ for 3 hours or more per day. Therefore, it was found that $74 \%$ of the students used the internet 3 hours or more in a day, and therefore, the majority of the foreign language teacher candidates participating in the research were active in the use of communication technologies.

Table 3: Information on the frequency of use of the internet by prospective foreign language teachers

\begin{tabular}{|l|l|l|l|l|}
\hline \multirow{2}{*}{$\begin{array}{l}\text { Frequency of Use of the } \\
\text { Internet }\end{array}$} & \multicolumn{2}{|l|}{ Female $(\mathrm{n}=58)$} & \multicolumn{2}{l|}{ Male $(\mathrm{n}=29)$} \\
\cline { 2 - 5 } & $f$ & $\%$ & $f$ & $\%$ \\
\hline 1 hour and less a day & 6 & 7 & 2 & 6 \\
\hline $1-2$ hours a day & 11 & 32 & 4 & 14 \\
\hline 3 hours and more a day & 41 & 71 & 23 & 80 \\
\hline
\end{tabular}

Table 4 shows the frequency and level of use of the major software products and communication services used in communication technologies by foreign language teacher candidates in daily and educational life. Accordingly, 100\% of them used Electronic Presentation, 98\% of them used word processing software and E-mail Software, 97\% of them used Internet Web Browsers and 90\% of them used E-mail Groups for communication and teaching purposes. In addition, it has been determined that $86 \%$ of the students use Weblogs, 76\% Educational software and 68\% Web-based Forums for teaching purposes only. In addition, it was found that $99 \%$ of the students were using the Smart Phones to chat and share information over the internet by using Chat software programs, but only $12 \%$ of the students used Short Message Service (SMS). 
Table 4: Frequency and usage levels of software products and communication services used in communication technologies

\begin{tabular}{|c|c|c|c|c|c|c|c|c|c|c|c|c|}
\hline \multirow{3}{*}{$\begin{array}{l}\text { Software Products and } \\
\text { Communication Services }\end{array}$} & \multicolumn{6}{|c|}{ Frequency of usage } & \multicolumn{6}{|c|}{ Level of Use } \\
\hline & \multirow{2}{*}{\multicolumn{2}{|c|}{ 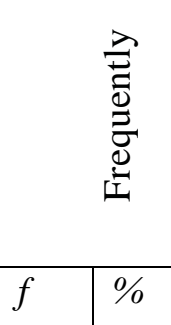 }} & \multicolumn{2}{|c|}{ 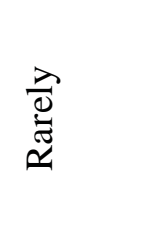 } & \multicolumn{2}{|l|}{$\begin{array}{l}\dot{0} \\
\dot{0} \\
z\end{array}$} & \multicolumn{2}{|r|}{ 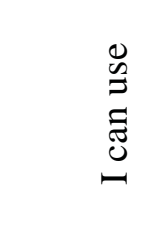 } & \multicolumn{2}{|c|}{ 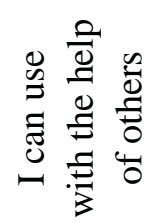 } & \multicolumn{2}{|c|}{ 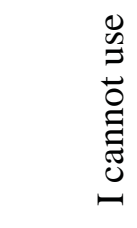 } \\
\hline & & & $f$ & $\%$ & $f$ & $\%$ & $f$ & $\%$ & $f$ & $\%$ & $f$ & $\%$ \\
\hline $\begin{array}{l}\text { Word processing software } \\
\text { (Microsoft Word) }\end{array}$ & 85 & 98 & 1 & 1 & 1 & 1 & 74 & 85 & 12 & 14 & 1 & 1 \\
\hline $\begin{array}{l}\text { Spreadsheet software } \\
\text { (Microsoft Excel) }\end{array}$ & 50 & 57 & 31 & 36 & 6 & 7 & 39 & 45 & 42 & 48 & 6 & 7 \\
\hline $\begin{array}{l}\text { Electronic Presentation } \\
\text { (Microsoft P. Point) }\end{array}$ & 87 & $\begin{array}{c}10 \\
0\end{array}$ & 0 & 0 & 0 & 0 & 76 & 87 & 11 & 13 & 0 & 0 \\
\hline $\begin{array}{l}\text { Web Browser (Mozilla } \\
\text { Firefox) }\end{array}$ & 84 & 97 & 3 & 3 & 0 & 0 & 85 & 97 & 2 & 3 & 0 & 0 \\
\hline E-mail Software (Gmail) & 85 & 98 & 1 & 1 & 1 & 1 & 84 & 96 & 2 & 3 & 1 & 1 \\
\hline $\begin{array}{l}\text { E-mail Groups (Google } \\
\text { Group) }\end{array}$ & 78 & 90 & 6 & 7 & 3 & 3 & 78 & 89 & 7 & 8 & 2 & 3 \\
\hline $\begin{array}{l}\text { Web-based Forum } \\
\text { (phpBB) }\end{array}$ & 59 & 68 & 21 & 24 & 7 & 8 & 40 & 46 & 44 & 51 & 3 & 4 \\
\hline Weblogs (Wikipedia) & 75 & 86 & 8 & 9 & 4 & 5 & 64 & 74 & 21 & 23 & 2 & 3 \\
\hline $\begin{array}{l}\text { Educational software } \\
\text { (TheSage) }\end{array}$ & 66 & 76 & 16 & 18 & 5 & 6 & 68 & 78 & 17 & 18 & 2 & 3 \\
\hline Chat software (WhatsApp) & 86 & 99 & 0 & 0 & 1 & 1 & 85 & 98 & 1 & 1 & 1 & 1 \\
\hline $\begin{array}{l}\text { Video Player (GOM } \\
\text { Player) }\end{array}$ & 82 & 94 & 4 & 5 & 1 & 1 & 79 & 91 & 7 & 8 & 1 & 1 \\
\hline Music Player (Dopamine) & 71 & 82 & 12 & 13 & 4 & 5 & 82 & 93 & 2 & 3 & 3 & 4 \\
\hline $\begin{array}{l}\text { SMS - Short Message } \\
\text { Service }\end{array}$ & 12 & 13 & 5 & 6 & 70 & 81 & 85 & 98 & 1 & 1 & 1 & 1 \\
\hline
\end{tabular}

The themes related to the factors that positively affect the beliefs of foreign language teacher candidates towards the use of instructional communication technologies are presented in Table 5. 
Table 5: Factors affecting the beliefs of foreign language teacher candidates' self-confidence in the use of instructional communication technologies

\begin{tabular}{|l|c|c|}
\hline Factors affecting positively & $f$ & $\%$ \\
\hline $\begin{array}{l}\text { Having sufficient knowledge and skills about communication technologies and } \\
\text { equipment }\end{array}$ & 3 & 4 \\
\hline $\begin{array}{l}\text { Having sufficient technological facilities related to communication technologies and } \\
\text { equipment }\end{array}$ & 4 & 5 \\
\hline Receiving positive feedback on the use of communication technologies & 8 & 9 \\
\hline Learning by discovering communication technologies and equipment & 12 & 13 \\
\hline Believing that communication technologies and equipment contribute to learning & 17 & 19 \\
\hline Using communication technology and equipment in course activities & 43 & 50 \\
\hline
\end{tabular}

According to this, the opinions expressed by half of the foreign language teacher candidates (50\%) showed that the use of these technologies in different course activities during their undergraduate education was one of the factors that positively affected the self-efficacy perception in terms of using instructional communication technologies. In this context, electronic presentations, preparation of assignments and other course activities for teaching purposes, especially in the context of individual and teamwork, provided the students with the opportunity to do adequate practice. On this basis, students stated that they have become proficient in the use of communication technologies for teaching purposes. Then $19 \%$ of the candidates believe that communication technologies contribute to learning is another theme derived from the opinions expressed. The students stated that observing that technology-supported courses are more enjoyable, and learning is more permanent, which affects their beliefs positively on this issue. In addition, it is stated that communication technologies supported courses enable students to be more interested in the course and increase motivation. The fact that the students who live with technology in daily life make use of these technologies in the lessons has been expressed as a positive factor that brings them closer to the lesson. $13 \%$ of the candidates emphasized the importance of learning by discovering communication technologies. Therefore, learning by discovering communication technologies is another theme obtained within the framework of opinions. The students stated that learning through discovering and practicing positively influenced their beliefs in the use of communication technologies for teaching purposes. From time to time, trying to make technology-assisted teaching practices on their own by sometimes getting the help of friends is another factor that strengthens the self-efficacy perceptions of prospective teachers. In addition to this, receiving positive feedback on the use of communication technologies and positive feedback from teachers and other students on the use of technology are among the factors that increase students' motivation to use technology for teaching purposes and affect their beliefs positively. In order to reach these findings, some excerpts of prospective teachers are given below.

Candidate teacher 1: "During my undergraduate studies, I used technology more than I have ever used before. I think my presentations and projects, or research assignments support this positively." 
Candidate teacher 2: "Our belief in this issue positively affected the fact that we made use of the internet during the preparation of presentations and the projector, smart board and so on during the presentation."

Candidate teacher 3: "My knowledge and experience with both foreign language education and other courses and the use of these technologies helped me greatly. What I learned by practicing increased my self-confidence."

Candidate teacher 4: "At the end of the presentations and the assignments we have prepared, we see that we are improving and our belief in ourselves is increasing at this rate."

Themes obtained within the framework of the opinions of the prospective foreign language teachers regarding the factors that negatively affect their beliefs about the use of instructional communication technologies are presented in Table 6.

Table 6: Factors affecting the beliefs of foreign language teacher candidates in themselves in the use of communication technologies for teaching purposes

\begin{tabular}{|l|c|c|}
\hline Factors affecting negatively & $f$ & $\%$ \\
\hline Failure to follow developments in communication technologies & 7 & 8 \\
\hline Lack of knowledge and experience in communication technologies and equipment & 9 & 10 \\
\hline Technical problems faced in the use of communication technologies and equipment & 14 & 16 \\
\hline Non-confidence in the use of communication technologies and equipment & 19 & 22 \\
\hline $\begin{array}{l}\text { Lack of technological infrastructure and security related to communication } \\
\text { technologies and equipment }\end{array}$ & 38 & 44 \\
\hline
\end{tabular}

Accordingly, the lack of technological infrastructure related to communication technologies expressed by almost half of the foreign language teacher candidates (44\%) and security is one of the most important factors affecting their beliefs about their use of communication technologies for teaching purposes. In the evaluation of the feedback received from prospective teachers, the lack of the technological infrastructure mentioned above was addressed in three dimensions. These dimensions are the thought of not having technological opportunities in the faculty and the schools that they will work in future and the financial problems that students encounter to purchase communication technologies. It can be said that lack of technological infrastructure has no direct negative effect on self-efficacy perception. However, when it is thought that teacher candidates' ability to use technology adequately and appropriately may affect selfefficacy perception positively, we can mention the effect of technology infrastructure on self-efficacy perception from a different perspective. In addition, it was stated that some reasons such as the fact that the devices used are old, technical failures and power failures negatively affect both teachers' and students' beliefs in using communication technologies for teaching purposes. As a matter of fact, $22 \%$ of the prospective teachers stated that not being confident about the use of communication technologies can be counted as a serious negative effect considering the possibility of encountering these problems. Consequently, $16 \%$ of prospective teachers emphasized the impact of technical problems encountered in 
the use of communication technologies. Some findings suggest that prospective teachers may feel inadequate in the use of communication technologies due to their inadequate knowledge to solve technical problems. $10 \%$ of the candidates stated that the lack of knowledge and experience related to communication technologies was a negativity, and $8 \%$ of the candidate students expressed that the inability to follow the developments in communication technologies that are rapidly developing emerged as a different negative effect. In addition, some students' negative beliefs about the use of technology are expressed in the form of lack of self-confidence about the use of information and communication technologies. To reach these findings, some excerpts of prospective teachers are given below.

Candidate teacher 1: "What I can call negative in myself are adapting to today's technology in a later and longer period than students, having difficulty in keeping up with technology tools and age and the difficulties experienced in this process."

Candidate teacher 2: "I sometimes hesitate about what to use and how. This affects me negatively. It sometimes makes us think that we are inadequate to use these tools."

Candidate teacher 3: "Inadequate technical disruptions from time to time seriously affected my belief in myself."

Candidate teacher 4: "It is negative to see that there is a possibility of not using enough technological tools. For example, you want to make a presentation, but you can't reach the tools you want."

\section{Conclusion and Recommendations}

Today, to provide interactive and participatory environments for its students, it has become inevitable for teachers to benefit from technology and technological equipment in the learning-teaching process. The use of communication technologies in the classroom and outside of the classroom becomes more important for the new generations to be raised under the guidance of prospective teachers, especially in this century when communication is at its peak. With this research, it has been tried to reveal the use of communication technologies, communication services and software products, communication technology hardware products and the factors affecting the self-efficacy beliefs of the candidates as positive and negative in this concept.

As a result of the study, we can conclude the following:

- It is seen that frequency and use of communication technologies in hardware products are generally high. One of the main reasons for this is that the electronic devices used in communication technology in the rapidly developing world have been accepted by the society not only in education but also in all areas of life, and they have devices that have variety and have reasonable prices and have a positive effect on the frequency and usage levels of prospective teachers.

- They stated that almost all of them find themselves capable of self-efficacy regarding the use of instructional communication technologies and hardware products. When the issue is analyzed based on gender, it was found that the majority of male and female participants had positive self-efficacy perception. 
- The frequency of internet usage with the most advanced communication technology is high among both male and female participants, and most of them use the internet for different purposes outside of education and most of the candidates use the internet for more than 3 hours a day.

- The frequency of using the main software products and communication services used in communication technologies in their daily and educational lives is very high and in parallel, the usability of these software products is high. Many candidates stated that they actively use this software during their education at university and therefore they gain practical experience. Accordingly, it was found that the self-efficacy beliefs of the candidates using the software were positively affected.

- The most important factor positively affecting their beliefs in the use of communication technologies for teaching purposes was the use of communication technologies and equipment in the course activities, and then communication technologies and equipment contributed positively to learning and teaching.

- Nearly half of them stated that the lack of technological infrastructure and security problems related to communication technologies are the main factors that negatively affect their beliefs about using communication technologies for teaching purposes. They stated that the self-efficacy of the candidates was adversely affected in the technical failures and problems encountered.

One of the most important steps in the integration of information and communication technologies in teacher education is to provide prospective teachers with original workspaces and technological infrastructure that they can learn by dealing with and experiencing technology. In a healthy practical environment, the use of communication technologies and equipment through individual and group works will be more efficient and will increase the candidates' self-efficacy beliefs to a higher level. As a matter of fact, research that will reveal the knowledge, skills and attitudes of prospective teachers in the use of communication technologies and equipment for teaching purposes will provide a basis for the planning and conducting of these instructional contexts. Some recommendations that can be evaluated within the framework of the research findings are:

- Instructors working in faculties of education should be encouraged to participate in specific seminars and various training programs where they can be more equipped and knowledgeable about communication technologies and equipment within the capabilities of the university.

- All faculty members working in different faculties and specialties in the faculties of education can plan course curriculums in which they can use their communication technologies and equipment.

- The faculties of education can be enriched with elective courses that deal with the use of communication technologies and equipment for teaching purposes as well as teaching field courses. These courses can be placed in the first years of education according to the possibilities of the university. Because in the first year, a student equipped with the necessary knowledge and skills is more likely to increase his / her experience until graduation.

- Prospective teachers should be provided with opportunities to use / apply their knowledge and skills throughout their education, and appropriate research assignments and projects should be planned.

- Computer and technology laboratories within the university can be opened to the use of candidate teachers outside the courses so that they can use these technologies more frequently. 
Developing positive self-efficacy in the areas of communication technologies and equipment of prospective teachers in all institutions where teachers or trainers are trained will positively affect their success in integrating these skills into their courses and guiding their students in these areas. A positive step will be taken for the candidate teachers who have the responsibility of educating next generations with the characteristics required by today's societies.

\section{References}

Bandura, A. (2001). Social cognitive theory: An agentic perspective. Annual Review of Psychology, 52(1), 1-26. https://doi.org/10.1146/annurev.psych.52.1.1

Bandura, A. (2006). Toward a psychology of human agency. Perspectives on Psychological Science, 1(2), 164-180. https://doi.org/10.1111/j.1745-6916.2006.00011.x

Bates, T., \& Poole, G. (2003). Effective teaching with technology in higher education: Foundations for success. ERIC Number: ED498562

Celik, B. (2019). A study on using the university library and reading habits of students: A Study on Tishk International University students in Erbil, Iraq. International Journal of English Linguistics, 9(4). https://doi:10.5539/ijel.v9n4p224

Chu, H. C. (2014). Potential negative effects of mobile learning on students' learning achievement and cognitive load-A format assessment perspective. Journal of Educational Technology \& Society, 17(1), 332-344. https://www.jstor.org/stable/jeductechsoci.17.1.332

Ertmer, P. A., Ottenbreit-Leftwich, A., \& York, C. S. (2006). Exemplary technology-using teachers: Perceptions of factors influencing success. Journal of Computing in Teacher Education, 23(2), 55-61.

Etikan, I., Musa, S. A., \& Alkassim, R. S. (2016). Comparison of convenience sampling and purposive sampling. American Journal of Theoretical and Applied Statistics, 5(1), 1-4. https://doi:10.11648/j.ajtas.20160501.11

Ghasemi, B., \& Hashemi, M. (2011). ICT: Newwave in English language learning/teaching. ProcediaSocial and Behavioral Sciences, 15, 3098-3102. https://doi.org/10.1016/j.sbspro.2011.04.252

Hoy, A. W., \& Spero, R. B. (2005). Changes in teacher efficacy during the early years of teaching: A comparison of four measures. Teaching and Teacher Education, 21(4), 343-356. https://doi.org/10.1016/j.tate.2005.01.007

Hsieh, H. F., \& Shannon, S. E. (2005). Three approaches to qualitative content analysis. Qualitative Health Research, 15(9), 1277-1288. https://doi.org/10.1177/1049732305276687

Huffman, A. H., Whetten, J., \& Huffman, W. H. (2013). Using technology in higher education: The influence of gender roles on technology self-efficacy. Computers in Human Behavior, 29(4), 1779-1786. https://doi.org/10.1016/j.chb.2013.02.012

Korkut, E., \& Akkoyunlu, B. (2008). Yabancı dil öğretmen adaylarının bilgi ve bilgisayar okuryazarlık öz-yeterlikleri. Hacettepe Üniversitesi Ĕgitim Fakültesi Dergisi, 34(34), 178-188.

Lee, K. W. (2000). English teachers' barriers to the use of computer-assisted language learning. The Internet TESL Journal, 6(12), 1-8. Retrieved from http://iteslj.org/Articles/Lee-CALLbarriers

Lombard, M., Snyder-Duch, J., \& Bracken, C. C. (2002). Content analysis in mass communication: Assessment and reporting of intercoder reliability. Human Communication Research, 28(4), 587-604. https://doi.org/10.1111/j.1468-2958.2002.tb00826.x

Markus, M. L. (1994). Finding a happy medium: Explaining the negative effects of electronic communication on social life at work. ACM Transactions on Information Systems (TOIS), 12(2), 119-149. https://doi.org/10.1145/196734.196738 
Mart, Ç.T. (2013a). A passionate teacher: Teacher commitment and dedication to student learning.

International Journal of Academic Research in Progressive Education and Development, 2(1), 437-442.

Mart, Ç.T. (2013b). Commitment to school and students. International Journal of Academic Research in Business and Social Sciences, 3(1), 336-340.

Mayer, R. E. (2013). Teaching and learning computer programming: Multiple research perspectives. Routledge.

Mertler, C. A., \& Reinhart, R. V. (2016). Advanced and multivariate statistical methods: Practical application and interpretation. Routledge.

Pajares, F. (2002). Self-efficacy beliefs in academic contexts: An outline. Retrieved on September 25, 2019 from: http://www.uky.edu/ eushe2/Pajares/efftalk.html

Shirbagi, N. (2011). A survey of Kurdistan university postgraguate students' attitudes to research and its relationship with their research self-effecacy. Traning \& Learning Researches, 2(1), 67-80.

Sysoyev, P. V., \& Evstigneev, M. N. (2014). Foreign language teachers' competency and competence in using information and communication technologies. Procedia-Social and Behavioral Sciences, 154, 82-86. https://doi.org/10.1016/j.sbspro.2014.10.116

Tschannen-Moran, M., \& Hoy, A. W. (2007). The differential antecedents of self-efficacy beliefs of novice and experienced teachers. Teaching and Teacher Education, 23(6), 944-956. https://doi.org/10.1016/j.tate.2006.05.003

Yildiz, Y. (2020). Reading habit and its role on students' academic success at language preparatory school: A Research on Tishk International University preparatory school students. Amazonia Investiga, 9(27), 189-194. https://doi.org/10.34069/AI/2020.27.03.20

Zimmerman, B. J. (2000). Self-efficacy: An essential motive to learn. Contemporary Educational Psychology, 25(1), 82-91. https://doi.org/10.1006/ceps.1999.1016 